\title{
INCLUSIVE URBAN AND COMMUNITY FORESTRY PROGRAMS: USING ALL OF YOUR COMMUNITY'S CULTURAL RESOURCES
}

\author{
by Jeffery $\mathrm{K}$. lles
}

\begin{abstract}
The thoroughly documented benefits from healthy, properly managed tree populations and less intensively managed greenbelts are not immediately apparent to all members of a community. Most citizen volunteers, local professional arborists and horticulturists, and the occasional politician that involve themselves in planting and maintaining their community's tree resource have at least a cursory understanding of the social, psychological, economic, and environmental benefits provided by trees. Yet many other segments of the population have had little to do with urban and community forestry issues. Enlisting the support of nontraditional audiences can only enhance urban and community forestry programs and strengthen the argument for increased funding needed to sustain this valuable resource.

Keywords. Nontraditional audience; co-culture; communication; diversity.
\end{abstract}

Generally speaking, traditional targets for urban and community forestry programs in the United States include financially comfortable, if not affluent, well-educated, predominantly Caucasian members of the community. Nontraditional urban forestry audiences, including the elderly, persons with disabilities, ethnic and racial minorities, and those with limited education and low incomes, are severely under-represented, even though trees are important to them (Ricard 1993; McDonough et al. 1994). Every community tree program will benefit when the effort is made to draw on the experiences and resources of the widest possible community.

\section{Our Communities Are Culturally Diverse}

The United States is entering a period in which cultural diversity is a fact of everyday life. In fact, by the turn of the century, minorities will make up $25 \%$ of the population, and at some point in the 21st century, Caucasians are expected to become a minority population in the United States (Klein 1990). These changing demographics indicate that almost everyone can expect to work, recre- ate, and volunteer with people who come from different backgrounds and cultures, and thus have different customs and beliefs.

Importance of culture. When people encounter the word "culture," they most often think of racial, ethnic, or national groups. But there are other dimensions of culture. Within a nation, regional differences can exert a powerful influence on human relationships and communication. Someone from northern Minnesota may find the life style of someone from southern Missouri so different that they might as well be from different countries. Race, ethnicity, and age also can shape behavior. For example, the customs, values, and attitudes of someone in their mid-20s may vary radically from those of their parents who were raised in the 1960s, or their grandparents who lived through economic calamity in the 1930s or World War II in the 1940s. Still other differences such as gender, sexual orientation, physical disabilities, religion, and socioeconomic background can create distinctive cultures (Adler and Elmhorst 1996).

All of these factors lead to a definition of "culture" as everything a group of people thinks (ideas, art, religion, values, and attitudes), does (norms, rules, laws, and language), and has (tools, technology, material, goods, and resources)

Shared ways of thinking lead people to define themselves as a distinct group, giving them a sense of commonality (Trenholm and Jensen 1992). The norms, values, and rules learned as part of cultural conditioning shape the way people view the world (McDonough et al. 1994). In essence, people use cultural rules as a screen or filter to interpret the behavior of others as appropriate or not (Devito 1997). The overwhelming influence of culture on communication led the 
famous anthropologist Edward Hall to assert that "culture is communication and communication is culture" (Hall 1959).

A walk through any large city or small town will reveal the United States is largely a collection of many different cultures. These cultures coexist somewhat separately, but also with each influencing the other. This coexistence has led some researchers to refer to these cultures as co-cultures (groups that have a clear identity within the encompassing culture) (Adler and Elmhorst 1996). In fact, the "melting pot" metaphor that suggests people should leave their native culture behind and adapt to their new culture is increasingly viewed as inaccurate. Other metaphors such as "tapestry" and "patchwork quilt" are now suggested as better ways to describe society (as mixtures of co-cultures) (Lustig and Koester 1993). Our society is becoming increasingly diverse and success in any endeavor does or will depend on communicating and working with people whose customs and values are different from our own.

\section{Back to the Trees}

Cities and towns in the midwestern United States are places where people of diverse cultural backgrounds live, yet the demographic richness of this region often is not reflected in community forestry programs. In particular, ethnic and racial minorities have been conspicuously absent from tree group volunteer rosters. Why do minorities choose not to participate in community forestry activities? Using surveys, the United Way organization learned minorities and women will not volunteer for any program that gives them an uncomfortable sense that

- they are mere "tokens"

- the program is "all talk and no action"

- they are isolated from other members of their minority or gender group

- the program seems irrelevant to their concerns

- they cannot communicate effectively with others because of language differences

- attitudes or behavior are discriminatory or perceived to be discriminatory

- they lack the qualifications to serve in a "high-powered" capacity
- what they have to say is not taken seriously

- they are being intimidated

- there are no real benefits to serving

- there are no role models

- those in charge overlook qualified minorities and women for key leadership roles.

However, possibly the biggest reason people fail to volunteer is because they weren't asked (Ricard 1993).

Contacting and involving new audiences in local community forestry projects require leadership, and a single person can make a difference. But to interest new, untapped audiences in a community tree program effectively requires that members of current administrative tree boards embrace and endorse the inclusion of all members of a community, and the first step is including influential members of the targeted cultural group in the planning process.

Clear communication and sensitivity are needed when approaching nontraditional audiences, particularly minority audiences (Spencer 1995). Key interviews with minority community leaders are efficient and cost-effective means of gaining insight into a potential audience's needs and wants. Political figures and leaders of neighborhood and worship groups are good information sources if they truly speak for the entire community and are not a faction. Finally, informal workshops engaging 10 to 20 people from the target audience in a discussion about community forestry issues will provide valuable insight; however, only innovative programs that respect the uniqueness of the people they are serving will work (Ricard 1993). People must feel empowered by the program. To include minorities and other nontraditional audiences, local tree groups should strive to

- establish a policy of "inclusiveness" and communicate a commitment to it (for example, by informing the media)

- place members of targeted groups in key decision-making positions

- enhance leadership skills of targeted groups by encouraging them to attend workshops and training programs

- change any structure or program that hinders inclusiveness 
- encourage greater sensitivity to cultural differences through invited speakers, workshops, or training sessions

- communicate the benefits that accrue to business and community as a result of inclusive policies

- solicit the help of businesses and professionals who are members of targeted audiences

- recruit new audiences by relying on established and respected institutions they support, such as places of worship, fraternal organizations, or business and professional associations

- allow a reasonable amount of time to achieve inclusiveness.

\section{Communication Across Cultures}

The process of listening and responding to people from different cultural backgrounds can be challenging. The greater the difference in culture between people, the greater the potential for misunderstanding and mistrust. Understanding how communication is affected by cultural conditioning can help prevent mistaken conclusions about the meaning of certain kinds of behavior. For example, the amount of talk or silence that is appropriate can differ from one ethnic co-culture to another (Adler and Elmhorst 1996). Most Native Americans and many other Asian American cultures value silence more highly than does mainstream U.S. culture. By contrast, AfricanAmerican and European-American cultures place a high value on verbal skills, and their members tend to speak more.

Attitudes toward conflict also differ from one ethnic co-culture to another (Adler and Elmhorst 1996). Asian, British, German, Native American, and Scandinavian cultures often prefer to not disagree assertively and directly. By contrast, many people with Greek, Italian, French, or South American background may prefer a direct, open conflict style.

Nonverbal standards such as eye contact also vary by co-culture (Adler and Elmhorst 1996). European Americans often associate eye contact with honesty and respect; however, Puerto Ricans and Native Americans show respect to persons in authority by not looking at them. Hopi and $\mathrm{Na}$ vajo people generally avoid steady eye contact because it is considered offensive, disrespectful, and rude. African-Americans tend to make more eye contact when speaking but not when listening, while European-Americans tend to make more continuous eye contact as they listen (Samovar and Porter 1997).

People with disabilities. Belonging to a coculture based on ethnicity or nationality requires years of immersion for full and complete understanding. By contrast, says Karen Stone, columnist for the Albuquerque Journal, "disability is a club anyone can join, anytime" (Stone 1995). Disabled people represent one group within American culture that is growing in numbers. Persons with disabilities constitute as much as $7 \%$ of the population and are the largest minority group in certain states (Wheratt 1988). Although the Americans with Disabilities Act (ADA) guarantees people with disabilities will receive reasonable accommodations and equal access to employment, buildings, transportation, and services, a disability removes a person from mainstream culture in many ways (Adler and Elmhorst 1996). Despite the lack of specific rules, guidelines are available to facilitate communication with people who have various types of disabilities (Adler and Elmhorst 1996):

- Blindness: When approaching a person who is blind, give your name and the names of others with you. When speaking in a group, address the person by name (there are no visual channels to indicate to whom your remarks are addressed). Do not speak more loudly or slowly than you normally would. If you are escorting a blind person, let them take your arm rather than trying to hold on to or move the person.

Finally, relax. Do not be embarrassed if you happen to use a common expression such as "see you later" that seems to relate to a person's disability.

- Hearing impairments: Touching or tapping the person on the shoulder or arm may be an acceptable way to get the attention of someone, at least until you find out if other approaches would be more welcome. 
Writing notes and using e-mail when possible can be a substitute for speech. When you do converse, face the person and speak clearly, especially if that person reads lips. Speaking loudly or overexaggerating articulations will not help. Make eye contact with and speak directly to the person, not to any interpreter who might be present. The interpreter is trained to watch you, so keep your focus on the person to whom your message is directed.

- Disabilities requiring the use of a wheelchair: The wheelchair is part of the person's personal territory. Do not lean or sprawl on someone's wheelchair or treat it as a public piece of furniture. When possible, put yourself on the same level as the person in the wheelchair instead of looking down.

- Speaking difficulties: Listen attentively without interrupting. If you do not understand, paraphrase what you believe was said, and allow the person to verify or clarify your understanding.

- Other disabilities: Offer to shake hands when introduced. People with limited hand use or an artificial limb can usually shake hands, and offering the left hand is an acceptable greeting.

\section{Final Thoughts}

Communicating with and involving people from nontraditional audiences in neighborhood urban and community forestry programs may seem a daunting task, but success will result when members of tree groups are flexible, patient, curious, have a sense of humor, and a demonstrate willingness to listen to others while respecting differences. As tree groups work to develop more inclusive community forestry programs, the following guidelines will smooth the transition:

- Learn about different cultures and subcultures (Beebe et al. 1996). Many cultural problems are not caused by malice but by a lack of knowledge. Learning about another person's values, beliefs, and behaviors can help in the understanding of their messages and underlying meaning.
- Be "other-oriented" (Beebe et al. 1996). Being other-oriented does not mean individuals should try to communicate in ways they are not equipped. Trying to use slang or jargon from another culture to impress someone may result in embarrass. ing errors and do more harm than good. Instead, by honestly responding to each other's interests, needs, and rules, people can establish mutual trust and pave the way for effective communication.

- Ask questions (Beebe et al. 1996). Asking questions is a simple technique for gathering information and also for confirming the accuracy of your expectations and assumptions. Be prepared to share information about yourself when posing a question to eliminate the perception that you are interrogating the person as a way to gain power and dominance.

- Develop mindfulness (Beebe et al. 1996). Remember that there are cultural differences, and try to keep them in your consciousness. Try to consider the other individual's frame of reference or world view.

- Develop flexibility and tolerate ambiguity (Beebe et al. 1996). When interacting with someone from another background, responding skills are crucial. Being willing to learn as you communicate, expecting some uncertainty, and "going with the flow" are important points to consider. And remember, every individual is unique, so cultural generalizations may not always apply.

- Avoid negative judgments (Beebe et al. 1996). Resist the thinking that your culture has all the answers. Suspend judgment and try to look at the situation as an outsider.

- Do not condescend (Adler and Elmhorst 1996). It is convenient to view people who are different as inferior. A first reaction to a person with a disability might be sympathy or pity. People who are learning English as a second language might sound less intelligent than native speakers. But in an effort to push these erroneous assumptions to the side, people often overcompensate. 
Be aware that excessive efforts to demonstrate an attitude of equality can come across as condescending. In the same way, well-intentioned but misguided efforts to lower expectations for members of some co-cultures can appear patronizing. Do not insult others by assuming that they are incapable of understanding or doing a good job.

- View diversity as an opportunity (Adler and Elmhorst 1996). Dealing with others who have different attitudes and customs takes patience and time. With the right attitude, cultural diversity can stop being an annoyance and instead become an opportunity. People from differing backgrounds can strengthen and enrich an organization.

Community forestry programs lose political clout and may render themselves obsolete if they maintain the status quo and either ignore or exclude nontraditional audiences. Programs that strive for cultural relevance facilitate connections between all segments of the community and foster communitywide respect for trees and the natural environment.

\section{Literature Cited}

Adler, R.B., and J.M. Elmhorst. 1996. Communicating at Work: Principles and Practices for Business and the Professions (5th ed.). McGraw-Hill, New York, NY.

Beebe, S.A., S.J. Beebe, and M.V. Redmond. 1996. Interpersonal Communication: Relating to Others. Allyn \& Bacon, Needham Heights, MA.

Devito, J.A. 1997. Human Communication: The Basic Course (7th ed.). Longman, New York, NY.

Hall, E. 1959. The Silent Language. Fawcett, Greenwich, CT.

Klein, E. 1990. Tomorrow's work force. Dun and Bradstreet's Reports (Jan-Feb):30-35.

Lustig, M.L., and J. Koester. 1993. Intercultural Competence: Interpersonal Communication Across Cultures. Harper Collins, New York, NY.

McDonough, M.H., K.E. Vachta, S.L. Funkhouser, and A.L. Gieche. 1994. Creating Community-Forestry Partnerships-A Participatory Approach. Dept. of Forestry, Michigan State University, East Lansing, MI.
Ricard, R.M. 1993. How important are minorities to tree programs? University of Connecticut Urban \& Community Forestry Fact Sheet, West Hartford, CT.

Samovar, L.A., and R.E. Porter. 1997. Intercultural Communication: A Reader (8th ed.). Wadsworth Publishing, Belmont, CA.

Spencer, D. 1995. Many cultures, one people: Planning diversity in education. The Public Garden 10(1): 18-21.

Stone, K.G. 1995. Disability Act everyone's responsibility in America. Albuquerque Journal, Feb. 19.

Trenholm, S., and A. Jensen. 1992. Interpersonal Communication (2nd ed.). Wadsworth Publishing, Belmont, CA.

Wheratt, R. 1988. Minnesota disabled to be heard. Star Tribune, Aug. 1.

Acknowledgements. I wish to express my deep appreciation to Gina Childs, William Graves, Maureen McDonough, and Janette Monear for their thoughtful review of this paper.

Journal paper no. J-17871 of the lowa Agriculture and Home Economics Experiment Station, Ames, lowa, Project No. 3229, and supported by Hatch Act and State of lowa funds.

College of Agriculture

Department of Horticulture

Horticulture Building

lowa State University

Ames, IA 50011-1100 
Zusammenfassung. Die sorgfältig dokumentierten Vorteile von gesunden, gepflegten Baumpopulationen und weniger intensiv unterhaltenen Grüngürteln sind nicht allen Mitgliedern eine Kommune bewußt. Meist haben nur interessierte Freiwillige, professionelle Baumpfleger, Gärtner und gelegentlich auch Politiker, die sich um den Erhalt von Bäumen in ihrer Region bemühen, ein Grundverständnis für die sozialen, psychologischen, ökonomischen und sich auf die Umwelt positiv auswirkenden Beiträge von Bäumen. Dennoch haben viele Bevölkerungsteile nur wenig mit urbanen Begrünungsprogrammen zu tun. Wenn die nicht-traditionellen Audienzen zur Unterstützung motiviert werden können, werden die urbanen Begrünungsprogramme nur verbessert und es unterstützt auch das Argument, daß größere öffentliche Mittel zur Erhaltung dieser wertvollen Resource erforderlich sind.
Resumen. Los beneficios completamente documentados de las poblaciones de árboles saludables y apropiadamente manejados y los menos intensivamente manejados cinturones verdes, no son inmediatamente aparentes para todos lo miembros de una comunidad. La mayoría de ciudadanos voluntarios, arboristas profesionales locales y horticultores, y los políticos ocasionales que se envuelven en la plantación y mantenimiento de los árboles de su comunidad, tiene al menos un entendimiento de los beneficios sociales, psicológicos, económicos y ambientales provistos por los árboles. Sin embargo, muchos otros segmentos de la población tienen poco que hacer con los temas del bosque urbano y comunal. Reciutar el soporte de audiencias no tradicionales puede realzar los programas forestales urbanos y comunales, y reforzar los argumentos para incrementar los fondos necesarios con el fin de sostener este valioso recurso. 